\title{
The effect of acidification of liquid whey protein concentrate on the flavor of spray-dried powder
}

\author{
Curtis W. Park, ${ }^{*}$ Eric Bastian, $†$ Brian Farkas, ${ }^{*}$ and MaryAnne Drake ${ }^{\star 1}$ \\ *Department of Food, Bioprocessing, and Nutrition Sciences, Southeast Dairy Foods Research Center, North Carolina State University, \\ Raleigh 27695 \\ †Glanbia Nutritionals, Twin Falls, ID 83301
}

\section{ABSTRACT}

Off-flavors in whey protein negatively influence consumer acceptance of whey protein ingredient applications. Clear acidic beverages are a common application of whey protein, and recent studies have demonstrated that beverage processing steps, including acidification, enhance off-flavor production from whey protein. The objective of this study was to determine the effect of preacidification of liquid ultrafiltered whey protein concentrate (WPC) before spray drying on flavor of dried WPC. Two experiments were performed to achieve the objective. In both experiments, Cheddar cheese whey was manufactured, fat-separated, pasteurized, bleached (250 $\mathrm{mg} / \mathrm{kg}$ of hydrogen peroxide), and ultrafiltered (UF) to obtain liquid WPC that was $13 \%$ solids (wt/ wt) and $80 \%$ protein on a solids basis. In experiment 1 , the liquid retentate was then acidified using a blend of phosphoric and citric acids to the following $\mathrm{pH}$ values: no acidification (control; $\mathrm{pH} 6.5$ ), $\mathrm{pH} 5.5$, or $\mathrm{pH}$ 3.5. The UF permeate was used to normalize the protein concentration of each treatment. The retentates were then spray dried. In experiment $2,150 \mu \mathrm{g} / \mathrm{kg}$ of deuterated hexanal $\left(\mathrm{D}_{12}\right.$-hexanal $)$ was added to each treatment, followed by acidification and spray drying. Both experiments were replicated 3 times. Flavor properties of the spray-dried WPC were evaluated by sensory and instrumental analyses in experiment 1 and by instrumental analysis in experiment 2. Preacidification to $\mathrm{pH} 3.5$ resulted in decreased cardboard flavor and aroma intensities and an increase in soapy flavor, with decreased concentrations of hexanal, heptanal, nonanal, decanal, dimethyl disulfide, and dimethyl trisulfide compared with spray drying at $\mathrm{pH} 6.5$ or 5.5. Adjustment to $\mathrm{pH} 5.5$ before spray drying increased cabbage flavor and increased concentrations of nonanal at evaluation $\mathrm{pH}$ values of 3.5 and 5.5 and dimethyl trisulfide at all evaluation $\mathrm{pH}$ values. In general, the

Received December 26, 2013.

Accepted March 14, 2014.

${ }^{1}$ Corresponding author: mdrake@ncsu.edu flavor effects of preacidification were consistent regardless of the $\mathrm{pH}$ to which the solutions were adjusted after spray drying. Preacidification to $\mathrm{pH} 3.5$ increased recovery of $\mathrm{D}_{12}$-hexanal in liquid WPC and decreased recovery of $\mathrm{D}_{12}$-hexanal in the resulting powder when evaluated at $\mathrm{pH} 6.5$ or 5.5. These results demonstrate that acidification of liquid WPC80 to $\mathrm{pH} 3.5$ before spray drying decreases off-flavors in spray-dried WPC and suggest that the mechanism for off-flavor reduction is the decreased protein interactions with volatile compounds at low $\mathrm{pH}$ in liquid WPC or the increased interactions between protein and volatile compounds in the resulting powder.

Key words: spray-dried whey powder, off-flavor, preacidification, whey protein concentrate

\section{INTRODUCTION}

Advances in processing technology have increased the production of whey protein concentrate. In 2010, approximately 194 million kilograms of whey protein concentrate (WPC; 25 to $89.9 \%$ protein) and approximately 27 million kilograms of whey protein isolate (WPI; $>90 \%$ protein) were produced in the United States (USDA, 2011). Both WPC and WPI, having high nutritional value and unique functional properties, are incorporated into sports drinks, meal replacement beverages, and infant formula. Protein beverages can be formulated at different acidity levels including neutral ( $\mathrm{pH}$ 6-7), mildly acidic ( $\mathrm{pH} 4-5$ ), or highly acidic $(\mathrm{pH}<3.5)$. Whey protein is least soluble at its isoelectric point ( $\mathrm{pH} 5.2)$ and solubility increases with decreasing $\mathrm{pH}$ (Pelegrine and Gasparetto, 2005), making WPC and WPI ideal for acidic beverages. Low-pH whey protein beverages have greater clarity, have the option of a milder thermal pasteurization process, and are regarded as shelf stable.

Astringency and off-flavors in both acidic and neutral $\mathrm{pH}$ whey protein beverages reduce consumer acceptance (Beecher et al., 2008; Childs and Drake, 2010; Evans et al., 2009, 2010). When WPC and WPI are used as ingredients, they are expected to be bland 
in flavor and colorless. Off-flavors in WPC and WPI (cardboard, cabbage, fatty, and potato) are generated from multiple sources, including cheese starter culture, processing, and storage conditions (Carunchia Whetstine et al., 2005; Wright et al., 2009; Liaw et al., 2010; Campbell et al., 2011b; Whitson et al., 2011). These off-flavors can carry through into beverages and negatively influence consumer acceptance (Evans et al., 2009, 2010; Wright et al., 2009). Volatile lipid oxidation products are primarily responsible for these off-flavors (Carunchia Whetstine et al., 2005; Wright et al., 2009; Whitson et al., 2010; Kang et al., 2012). Bleaching of liquid whey is one of the primary sources of off-flavors in dried whey protein products (Croissant et al., 2009; Kang et al., 2012; Listiyani et al., 2011; Jervis et al., 2012). Other unit operations, including liquid storage time, dry storage, and instantization, can also negatively influence whey protein flavor (Wright et al., 2009; Whitson et al., 2011).

Recent studies have demonstrated that beverage processing steps (acidification and heat treatment) may also have detrimental effects on WPI flavor contributions (White et al., 2013). Dried and acidified WPI products are commercially available and ready-made for beverages. These proteins are acidified before spraydrying and provide an ingredient that is purportedly lower in aromatic flavor intensities. To our knowledge, no published studies have investigated the effect of acidification before spray drying on the flavor of WPC. The objective of this study was to investigate whether preacidification (before spray drying) affected the flavor of the subsequent powder compared with acidification after rehydration of the dried powder. This objective was achieved by application of sensory and instrumental analyses of WPC made from bleached Cheddar whey that was spray dried at different $\mathrm{pH}$ values $(6.5,5.5$, and 3.5). A subsequent study investigated the mechanism of flavor reduction using a stable isotope.

\section{MATERIALS AND METHODS}

\section{Experimental Design}

Two experiments (experiments 1 and 2) were included in this study. The purpose of experiment 1 was to determine the effect of acidification of liquid WPC on the flavor of spray-dried WPC. To make WPC, liquid whey was pasteurized, separated, bleached, ultrafiltered, and diafiltered to $13 \%$ solids (wt/wt) with $80 \%$ (wt/wt) of the solids as protein. Each batch of liquid WPC80 retentate was adjusted to $\mathrm{pH} 6.5,5.5$, or 3.5. Fresh liquid permeate was added to the $\mathrm{pH} 6.5$ and 5.5 treatments to dilute the protein to the same level as that of the $\mathrm{pH} 3.5$ treatment. The resulting retentates were $74 \%$ protein on a dry weight basis and were subsequently spray dried, giving WPC75. The entire experiment was replicated 3 times.

The purpose of experiment 2 was to investigate volatile compound association with WPC at different $\mathrm{pH}$ values $(6.5,5.5$, and 3.5$)$ before and after spray drying. One batch of liquid Cheddar whey was manufactured, pasteurized, separated, bleached, ultrafiltered, and diafiltered to produce liquid WPC80 retentate similar in composition to that of experiment 1 . Retentate was then split into 3 equal portions and spiked with deuterated $\left(D_{12}\right)$-hexanal $(150 \mu \mathrm{g} / \mathrm{kg}$; CDN Isotopes, Quebec, QC, Canada). The pH of each portion of WPC80 retentate was then adjusted to $6.5,5.5$, or 3.5 and solids adjusted with liquid permeate added to the $\mathrm{pH} 6.5$ and 5.5 treatments as in experiment 1 . The retentates (WPC75) were then spray dried. The entire experiment was replicated 3 times.

\section{Liquid Whey and WPC80 Production}

Raw whole milk was obtained from the North Carolina State University Dairy Research and Education Unit (Raleigh). The milk was vat pasteurized (model MPD1050, Micro Process Design, D\&F Equipment Co., McLeansville, NC) at $63^{\circ} \mathrm{C}$ for $30 \mathrm{~min} ; 195 \mathrm{~kg}$ was pasteurized for use on $\mathrm{d} 1$, and $117 \mathrm{~kg}$ was pasteurized, cooled, and stored overnight at $4^{\circ} \mathrm{C}$ for use on $\mathrm{d}$ 2. The milk was then cooled to $31^{\circ} \mathrm{C}$ and transferred to a cheese vat (model 4MX, Kusel Equipment Co., Watertown, WI). Mesophilic starter culture containing Lactococcus lactis ssp. lactis and Lactococcus lactis ssp. cremoris (Danisco Choozit MA11 LYO, Dairy Connection Inc., Madison, WI) was added at the rate of 50 dairy culture units $/ 454 \mathrm{~kg}$ of milk. A calcium chloride solution (50\% wt/vol, Dairy Connection Inc.) was also added at the rate of $0.39 \mathrm{~mL} / \mathrm{kg}$ of milk. The milk was then allowed to ripen for $60 \mathrm{~min}$. Double-strength annatto color (Cheese Color DS Double Strength, Dairy Connection Inc.) was added after $30 \mathrm{~min}$ of ripening at the rate of $15 \mathrm{~mL} / 454 \mathrm{~kg}$ of milk, diluted 20 times in deionized water. Then, the milk was coagulated with double-strength recombinant rennet (Dairy Connection Inc.) for $30 \mathrm{~min}$ at a rate of $0.09 \mathrm{~mL} / \mathrm{kg}$ of milk diluted 80 times in deionized water. The coagulum was then cut and the curd was allowed to rest for $5 \mathrm{~min}$. The curd and whey were stirred for $30 \mathrm{~min}$ while the temperature was increased gradually to $39^{\circ} \mathrm{C}$. The $\mathrm{pH}$ was monitored and once a $\mathrm{pH}$ of 6.35 was achieved, the whey was drained through a sieve to remove cheese fines. Fat in drained whey was separated using a hot bowl centrifugal separator (model SI600E, Agri-Lac, Miami, FL). After separation, the whey was pasteurized at $63^{\circ} \mathrm{C}$ for $30 \mathrm{~min}$. Following pasteurization, the 
whey from d 1 was split into 2 batches of about 68 $\mathrm{kg}$ each in 60-L stainless steel kettles (model 601BP, Polar Ware Company, Kiel, WI). All of the whey from d 2 was used as one batch. Treatment assignment to each batch was randomized and balanced across the 3 replications. Each batch was bleached with $250 \mu \mathrm{g} / \mathrm{kg}$ hydrogen peroxide (35\% wt/vol, VWR International, Westchester, PA) for $1 \mathrm{~h}$ at $60^{\circ} \mathrm{C}$. Catalase $(20 \mathrm{mg} /$ kg, FoodPro CAT, Danisco, New Century, NJ) was added at $20 \mu \mathrm{g} / \mathrm{kg}$ to remove the hydrogen peroxide upon completion of bleaching. The inactivation of the hydrogen peroxide was confirmed by using EM Quant peroxide test strips (EMD Chemicals Inc., Gibbstown, NJ).

After bleaching, the whey was subjected to UF and diafiltration to concentrate the protein to $80 \%$ on a dry weight basis ( $13 \%$ solids). Before UF, the membrane cartridges were cleaned with a $0.1 \mathrm{~N}$ sodium hydroxide solution (VWR International) followed by a rinsing of deionized water. After the rinse step, each batch of whey was concentrated using a UF system (model Pellicon 2, Millipore Inc., Billerica, MA) using 5 cartridges of polyethersulfone membrane filters (model P2B010V05, nominal separation cutoff $=10,000 \mathrm{kDa}$, surface area $=0.5 \mathrm{~m}^{2}$ ). The pump used to circulate the product was a variable-speed peristaltic pump (model 77410-10, Cole Palmer, Vernon Hills, IL) equipped with model 77601-00 pumpheads with silicone tubing (model 96440-73, Cole Palmer).

The flux during UF was calculated every $15 \mathrm{~min}$. Diafiltration was used to aid the removal of lactose and minerals to further concentrate the protein. Total deionized water addition was equal to $50 \%$ of the original weight of the liquid whey. The protein concentration was confirmed with a Sprint Rapid Protein Analyzer (CEM Corp., Matthews, NC). Percentage solids were analyzed using a Smart System 5 moisture/solids analyzer (CEM Corp.). The total time for UF was approximately $2.5 \mathrm{~h}$.

Once the WPC was made, the 3 batches were subjected to one of the following treatments: control $\mathrm{pH}$ (6.5), $\mathrm{pH} 5.5$, and $\mathrm{pH}$ 3.5. For experiment 2, $\mathrm{D}_{12}$-hexanal (CDN Isotopes) was added $(150 \mu \mathrm{g} / \mathrm{kg})$ to each treatment before acidification. The acidified samples were acidified using a blend of $3.66 \mathrm{M}$ phosphoric (Mallinckrodt Baker Inc., Phillipsburg, NJ) and 1.24 $M$ citric (VWR International) acids. Because acidification to $\mathrm{pH}$ 3.5 diluted the protein concentration, UF permeate was added to the control and $\mathrm{pH} 5.5$ retentates to equalize the protein concentration across all samples. Thus, the control retentate was diluted with permeate, $\mathrm{pH} 5.5$ retentate with permeate and acid, and $\mathrm{pH} 3.5$ retentate with acid. It was determined that it was more important to equalize the protein concentration during spray drying than to keep the composition the same because the composition would be different in the $\mathrm{pH} 5.5$ and 3.5 retentates due to addition of acid. The retentates were dried in a spray dryer (model Lab 1, Anhydro Inc., Soeberg, Denmark) with an inlet temperature of $200^{\circ} \mathrm{C}$ and outlet temperature of $90^{\circ} \mathrm{C}$. The dried powdered samples were collected in Mylar bags (TF-4000, Impak Corp., Central City, SD) and stored at $-80^{\circ} \mathrm{C}$ until subsequent analyses. Both experiments were replicated 3 times.

\section{Proximate Analysis}

The percentage moisture of the dried whey proteins was measured using a vacuum oven (AOAC International, 2000; method 990.20: 33.2.44). The fat content was measured using a modified Mojonnier ether extraction (AOAC International, 2000; method 932.06; 33.5.08). Total protein was measured using the Kjeldahl method (AOAC International, 2000; method 991.20; 33.2.11) by multiplying total $\mathrm{N}$ by a factor of 6.38 .

\section{Descriptive Analysis}

All sensory testing was performed in compliance with the North Carolina State University Institutional Review Board for Human Subjects guidelines. Spraydried powders were collected and rehydrated to $10 \%$ solids (wt/vol) in deionized (DI) water. There were 3 $\mathrm{pH}$ values from the 3 treatments: 6.5, 5.5, and 3.5. Each of these treatments was rehydrated to $10 \%$ solids (wt/ vol) in DI water and either acidified or neutralized to each of the following $\mathrm{pH}$ values: $6.5,5.5$, and 3.5. In total, every experimental replication had 9 samples for evaluation. The acid used to acidify the samples was a $10 \%$ solids (wt/vol) solution of a mixture of $0.61 \mathrm{M}$ phosphoric (Mallinkrodt Chemical, Phillipsburg, NJ) and $0.21 M$ citric (J. T. Baker, Mallinkrodt Baker, Phillipsburg, NJ) acids (White et al., 2013), and the base used to neutralize the samples was a $10 \%$ solids (wt/vol) solution of $2.5 \mathrm{M}$ sodium hydroxide (VWR International). All samples were evaluated at $10 \%$ solids (wt/vol).

The rehydrated powders were dispensed into 3-digitcoded soufflé cups (Solo Cup, Highland Park, IL), lidded, and tempered to $21^{\circ} \mathrm{C}$. Aromatic intensities were evaluated by trained panelists $(\mathrm{n}=8)$ using an established sensory language for dried dairy ingredients and a 0 - to 15-point Spectrum intensity scale (Wright et al., 2009). Panelists were between the ages of 23 and $45 \mathrm{yr}$ and each had over $150 \mathrm{~h}$ of experience with descriptive analysis of dried dairy ingredients. Panelists expectorated samples and were provided with room temperature DI water for palate cleansing. Each sample was 
evaluated in duplicate by each panelist. Compusense Five version 4.8 (Compusense, Guelph, ON, Canada) was used for data collection.

\section{Instrumental Volatile Compound Analysis}

Spray-dried powders were collected and rehydrated to $10 \%$ solids (wt/vol) in HPLC-grade water (Campbell et al., 2011a). Powders were $\mathrm{pH}$ adjusted as described for descriptive analysis. Volatile compounds were extracted by headspace-solid phase microextraction (SPME)-GC-MS. A CombiPal Autosampler (CTC Analytics, Zwingen, Switzerland) was used for injections. All injections were made on an Agilent 6890N GC with 5973 inertmass selective detector with a ZB- 5 ms $(30 \mathrm{~m}$ $\times 0.25 \mathrm{~mm}$ i.d. $\times 0.25 \mu \mathrm{m})$ column (Phenomenex, Torrance, CA). After neutralization or acidification, $5 \mathrm{~mL}$ of each sample was added to $20-\mathrm{mL}$ solid phase microextraction vials (MicroLiter Analytical Supplies Inc., Suwanee, GA). An internal standard compound $(10 \mu \mathrm{L}$ of $81 \mathrm{mg} / \mathrm{kg}$ 2-methyl-3-heptanone in ether; Sigma Aldrich, St. Louis, MO) was added to each vial along with $0.5 \mathrm{~g}$ of sodium chloride (VWR International). The GC method was adapted from Campbell et al. (2011a). Each sample was prepared in triplicate. Equilibration took place over $25 \mathrm{~min}$ at $40^{\circ} \mathrm{C}$ while the samples were agitated at $250 \mathrm{rpm}$. A 1-cm divinylbenzene (DVB)/ Carboxen/polydimethylsiloxane (PDMS) fiber (Supelco, Bellefonte, PA) was used. Compounds were identified using the National Institute of Standards and Technology (NIST, 2005) mass spectral database and authentic standards injected under identical conditions. Compounds of interest (Campbell et al., 2011a; Jervis et al., 2012; White et al., 2013) were quantified either by relative abundance using the internal standard or by constructing 5-point standard curves, with $\mathrm{D}_{12}$-hexanal, $\mathrm{D}_{18}$-octanal, and $\mathrm{D}_{6}$-dimethyl disulfide (DMDS; CDN Isotopes) added to samples that were $\mathrm{pH}$ adjusted as described previously.

For experiment $2, \mathrm{D}_{12}$-hexanal was monitored using selective ion monitoring mode with an ion mass of 64 used for quantification. Both liquid retentate and rehydrated powders were analyzed at $10 \%$ solids (wt/ vol). Five-point standard curves were constructed using $\mathrm{D}_{12}$-hexanal in treated samples that were not originally spiked with $\mathrm{D}_{12}$-hexanal.

\section{Statistical Analysis}

The data were analyzed with 2-way ANOVA with means separation using SAS software (version 9.3, SAS Institute Inc., Cary, NC). Fisher's least significant difference (LSD) test was used to analyze differences among sample means.

\section{RESULTS}

\section{Proximate Analysis}

The fat and moisture of the spray-dried WPC produced in experiments 1 and 2 were consistent $(P>$ 0.05). The fat content averaged $3.94 \% \pm 0.47$ and the moisture content averaged $4.85 \% \pm 0.70$. The protein content was $76.3 \% \pm 0.40,74.8 \% \pm 1.53$, and $73.8 \%$ \pm 0.65 for the control $(\mathrm{pH} 6.5), \mathrm{pH} 5.5$, and $\mathrm{pH} 3.5$ treatments, respectively, with the protein contents of the control and $\mathrm{pH} 3.5$ being significantly different $(P$ $<0.05)$. Although the protein content did vary significantly between treatments, the difference in protein content observed here represents a difference that would be within specifications from an industrial WPC manufacturer. The spray-dried WPC from experiment 2 did not differ $(P>0.05)$ in fat, moisture, or protein composition from the powders in experiment 1.

\section{Sensory and Volatile Compound Analysis}

Experiment 1. Off-flavors in whey protein ingredients are mainly attributed to volatile lipid oxidation products and are mainly aldehydes and ketones (Croissant et al., 2009; Evans et al., 2010; Whitson et al., 2010). Many of the volatile lipid oxidation products in dried whey protein ingredients are above sensory threshold values and thus contribute to the flavor of the whey proteins (Whitson et al., 2010). Starter culture, light exposure, storage, heat treatment, and bleaching can all increase volatile lipid oxidation products in whey proteins (Tomaino et al., 2004; Croissant et al., 2009; Campbell et al., 2011b; Liaw et al., 2011; Jervis et al., 2012). Spray drying liquid WPC at pH 5.5 and 3.5 had significant effects on the flavor of the subsequent powder compared with the control ( $\mathrm{pH}$ 6.5; Table 1, Figure 1). Interactions between spray-drying $\mathrm{pH}$ and evaluation $\mathrm{pH}$ were significant for overall aroma, sweet aromatic, cardboard, and soapy flavor intensities $(P<$ $0.05)$. In general, samples spray dried at $\mathrm{pH} 6.5$ or $\mathrm{pH}$ 5.5 were characterized by increased aroma and cardboard flavors at all evaluation $\mathrm{pH}$ values and increased sweet aromatic at an evaluation $\mathrm{pH}$ of $6.5(P<0.05$; Table 1). Spray drying at $\mathrm{pH} 5.5$ decreased sweet aromatic flavor at an evaluation $\mathrm{pH}$ of 6.5 and increased cabbage flavor at all evaluation $\mathrm{pH}$ values, and did not affect aroma or cardboard flavor intensities compared with spray drying at $\mathrm{pH} 6.5(P<0.05)$. At all evaluation $\mathrm{pH}$ values, WPC acidified to $\mathrm{pH} 3.5$ before spray drying was characterized by increased soapy flavor and decreased aroma impact and cardboard flavor (Figure 1). An evaluation $\mathrm{pH}$ of 3.5 decreased aroma and cardboard flavor in WPC spray dried at $\mathrm{pH} 5.5$ and 6.5, but 


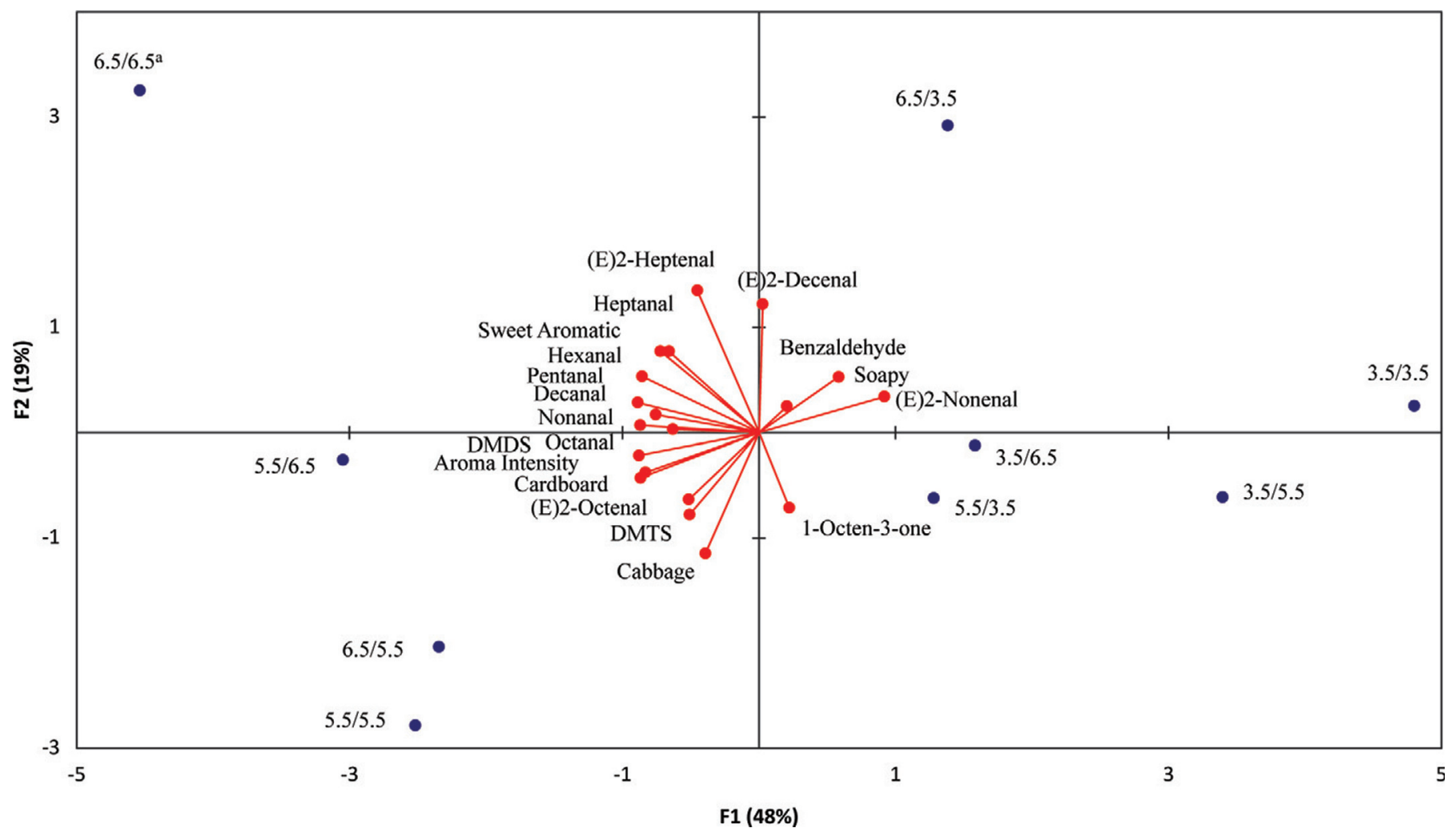

Figure 1. Principal component biplot of sensory and volatile compound analyses of rehydrated whey protein concentrate spray dried at different $\mathrm{pH}$ values. The first value in each pair represents the spray-dry $\mathrm{pH}$ and the second value represents the evaluation $\mathrm{pH}$. DMDS $=\mathrm{D}_{6^{-}}$ dimethyl disulfide; DMTS = dimethyl trisulfide. Color version available in the online PDF.

WPC spray dried at $\mathrm{pH} 3.5$ had the lowest intensities, regardless of the evaluation $\mathrm{pH}$, compared with WPC spray dried at $\mathrm{pH} 6.5$ or $5.5(P<0.05$; Table 1 , Figure $1)$. Evaluation of WPC at $\mathrm{pH} 5.5$ increased cabbage flavor intensity for WPC spray dried at $\mathrm{pH} 6.5$ or 5.5 but had no effect on WPC spray dried at pH $3.5(P<$ 0.05).

Consistent with sensory results, interactions between spray-drying $\mathrm{pH}$ and evaluation $\mathrm{pH}$ were significant for all volatile compounds except decanal and 2,4-nonadienal $(P<0.05$; Figure 1 , Table 2$)$. When evaluated at $\mathrm{pH} 6.5$ or 5.5 , WPC that were spray dried at $\mathrm{pH} 6.5$ and 5.5 were characterized by increased concentrations of the aldehydes hexanal, pentanal, decanal, nonanal, and the protein degradation product DMDS (Figure 1; Table 2). Acidification to $\mathrm{pH} 3.5$ before spray drying decreased concentrations of hexanal, heptanal, nonanal, and dimethyl trisulfide (DMTS) at each of the

Table 1. Descriptive analysis means for rehydrated (10\% solids) whey protein concentrate spray dried at different $\mathrm{pH}$ values $(6.5,5.5$, and 3.5$)$ and evaluated at different $\mathrm{pH}$ values $(6.5,5.5 \text {, and } 3.5)^{1}$

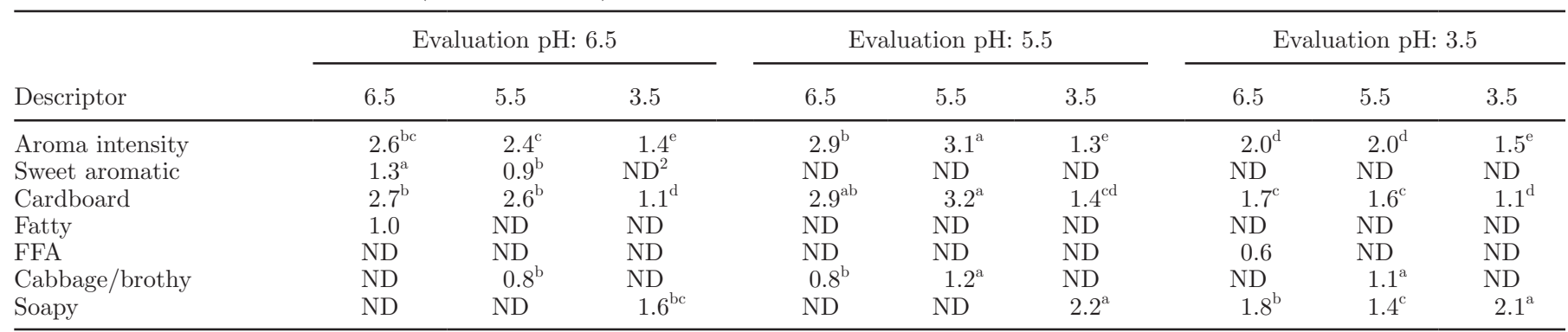

${ }^{\mathrm{a}-\mathrm{e}}$ Means in a row followed by a different letter are different $(P \leq 0.05)$.

${ }^{1}$ Attributes were scored using a 0- to 15-point universal intensity scale (Wright et al., 2009). Most dairy flavors fall between 0 and 4 on this scale. ${ }^{2} \mathrm{ND}=$ not detected. 
evaluation $\mathrm{pH}$ values compared with WPC spray dried at $\mathrm{pH} 6.5$ or $5.5(P<0.05$; Table 2$)$. Consistent with sensory results for cabbage flavor, an evaluation $\mathrm{pH}$ of 5.5 increased DMTS concentration in WPC spray dried at $\mathrm{pH} 6.5$ or $3.5(P<0.05)$. The evaluation $\mathrm{pH}$ of 3.5 decreased concentrations of pentanal and hexanal for all treatments but the WPC spray dried at $\mathrm{pH} 3.5$ were always lower in the above compounds than those spray dried at $\mathrm{pH} 6.5$ or 5.5 except for pentanal at an evaluation $\mathrm{pH}$ of $3.5(P<0.05)$. These results demonstrate that acidification of WPC retentate before spray drying reduced off-flavor intensities and their corresponding volatile compounds and that the evaluation $\mathrm{pH}$ had an effect on volatile compound recovery but spray drying $\mathrm{pH}$ had a greater effect.

Experiment 2. Data from experiment 1 indicated that acidification of WPC retentate to $\mathrm{pH} 3.5$ reduced cardboard and cabbage flavor intensities along with lipid and protein volatile oxidation compounds. Experiment 2 was devised to further explain the mechanism for the reduction of oxidation volatile compounds. The decrease in volatile lipid oxidation compounds (VLOC) in WPC spray dried at $\mathrm{pH} 3.5$, observed in experiment 1, may be attributed to decreased lipid oxidation, increased volatilization during spray drying, or an increase in association between the VLOC and whey protein. No differences in VLOC were observed when WPC34 was spray dried versus freeze dried, suggesting that lipid oxidation during spray drying is minimal (Evans et al., 2009). Additionally, due to the short residence time and the fact that spray-drying droplets usually do not reach temperatures above $60^{\circ} \mathrm{C}$, it is unlikely that a reduction of lipid oxidation is the mechanism (Schuck, 2013). A decrease in lipid oxidation or increased volatility during spray drying would reduce the amount of VLOC present and an increase in association with the whey protein would reduce the amount of VLOC in the headspace and thus reduce off-flavor intensity.

Hexanal was chosen for experiment 2 because it was one of the aldehydes from experiment 1 that showed a dramatic decrease in concentration in samples spray dried at $\mathrm{pH} 3.5$ and is also a product of lipid oxidation (Frankel et al., 1981). Deuterated hexanal $\left(\mathrm{D}_{12^{-}}\right.$ hexanal) is not produced naturally during lipid oxidation of WPC but displays the chemical properties of hexanal. Increased recovery of $\mathrm{D}_{12}$-hexanal in the liquid retentate was observed at $\mathrm{pH} 3.5$ compared with $\mathrm{pH}$ 5.5 or $6.5(P<0.05 ; 40.8$ vs. 20.0 vs. $11.6 \mu \mathrm{g} / \mathrm{kg}$, respectively). Interactions were significant for spray-dry $\mathrm{pH}$ and evaluation $\mathrm{pH}$ in the WPC powders $(P<0.05$; Table 3). Recovery of $\mathrm{D}_{12}$-hexanal was lower in WPC spray dried at $\mathrm{pH} 3.5$ than in WPC spray dried at $\mathrm{pH} 6.5$ or 5.5 when evaluated at $\mathrm{pH} 6.5$ (24.7 vs. 59.7 vs. $47.2 \mu \mathrm{g} / \mathrm{kg}$, respectively) and $\mathrm{pH} 5.5$ (18.2 vs. 35.5 vs. $27.5 \mu \mathrm{g} / \mathrm{kg}$, respectively; $P<0.05$ ). When evaluated at $\mathrm{pH} 3.5, \mathrm{D}_{12}$-hexanal recovery decreased in each treatment and was not different between treatments $(P>0.05$; Table 3$)$. This result was consistent with the volatile compound analysis in experiment 1 , where

Table 2. Concentration $(\mu \mathrm{g} / \mathrm{kg})$ of selected volatile compounds in whey protein concentrate spray dried at different $\mathrm{pH}$ values $(6.5,5.5$, and $3.5)$ and evaluated at different $\mathrm{pH}$ values $(6.5,5.5$, and 3.5$)$

\begin{tabular}{|c|c|c|c|c|c|c|c|c|c|}
\hline \multirow{2}{*}{$\begin{array}{l}\text { Volatile } \\
\text { compound }\end{array}$} & \multicolumn{3}{|c|}{ Evaluation pH: 6.5} & \multicolumn{3}{|c|}{ Evaluation pH: 5.5} & \multicolumn{3}{|c|}{ Evaluation $\mathrm{pH}: 3.5$} \\
\hline & 6.5 & 5.5 & 3.5 & 6.5 & 5.5 & 3.5 & 6.5 & 5.5 & 3.5 \\
\hline Pentanal $^{1}$ & $13.0^{\mathrm{a}}$ & $9.99^{\mathrm{b}}$ & $4.94^{\mathrm{d}}$ & $7.29^{\mathrm{c}}$ & $8.82^{\mathrm{b}}$ & $4.80^{\mathrm{d}}$ & $4.89^{\mathrm{d}}$ & $3.55^{\mathrm{e}}$ & $3.21^{\mathrm{e}}$ \\
\hline Hexanal $^{1}$ & $260^{\mathrm{a}}$ & $151^{\mathrm{c}}$ & $106^{\mathrm{e}}$ & $190^{\mathrm{b}}$ & $129^{\mathrm{d}}$ & $77.6^{\mathrm{f}}$ & $144^{\mathrm{c}}$ & $102^{\mathrm{e}}$ & $27.9^{\mathrm{g}}$ \\
\hline Heptanal $^{1}$ & $23.6^{\mathrm{a}}$ & $15.2^{\mathrm{c}}$ & $12.4^{\mathrm{d}}$ & $15.6^{\mathrm{c}}$ & $15.6^{\mathrm{c}}$ & $12.5^{\mathrm{d}}$ & $19.4^{\mathrm{b}}$ & $14.5^{\mathrm{cd}}$ & $6.38^{\mathrm{e}}$ \\
\hline (E) 2-Heptenal ${ }^{1}$ & $12.2^{\mathrm{a}}$ & $6.08^{c}$ & $3.85^{\text {de }}$ & $2.38^{\mathrm{ef}}$ & $2.01^{\mathrm{f}}$ & $1.55^{\mathrm{f}}$ & $9.12^{\mathrm{b}}$ & $4.62^{\mathrm{cd}}$ & $2.29^{\mathrm{f}}$ \\
\hline Octanal $^{2}$ & $14.8^{\mathrm{a}}$ & $11.1^{\mathrm{b}}$ & $13.9^{\mathrm{a}}$ & $11.8^{\mathrm{b}}$ & $9.84^{\mathrm{c}}$ & $8.58^{\mathrm{d}}$ & $6.9^{\mathrm{e}}$ & $11.9^{\mathrm{b}}$ & $5.09^{\mathrm{f}}$ \\
\hline (E)2-Octenal ${ }^{2}$ & $5.96^{\mathrm{bc}}$ & $3.48^{\mathrm{d}}$ & $6.30^{\mathrm{bc}}$ & $10.5^{\mathrm{a}}$ & $6.70^{\mathrm{b}}$ & $2.00^{\mathrm{e}}$ & $3.16^{\mathrm{d}}$ & $5.34^{\mathrm{c}}$ & $3.34^{\mathrm{d}}$ \\
\hline Nonanal $^{2}$ & $109^{\mathrm{a}}$ & $113^{\mathrm{a}}$ & $77.2^{\mathrm{cd}}$ & $76.1^{\mathrm{d}}$ & $97.3^{\mathrm{b}}$ & $60.1^{\mathrm{e}}$ & $70.2^{\mathrm{d}}$ & $84.8^{\mathrm{c}}$ & $41.1^{\mathrm{f}}$ \\
\hline (E)2-Nonenal ${ }^{2}$ & $1.20^{\mathrm{c}}$ & $0.310^{\mathrm{e}}$ & $0.450^{\mathrm{e}}$ & $3.49^{\mathrm{a}}$ & $0.683^{\mathrm{de}}$ & $0.832^{\mathrm{cd}}$ & $3.49^{\mathrm{a}}$ & $2.76^{\mathrm{b}}$ & $2.39^{\mathrm{b}}$ \\
\hline Decanal $^{2}$ & $7.05^{\mathrm{ab}}$ & $6.99^{\mathrm{ab}}$ & $4.27^{\mathrm{c}}$ & $7.56^{\mathrm{a}}$ & $6.60^{\mathrm{b}}$ & $4.01^{\mathrm{c}}$ & $7.45^{\mathrm{a}}$ & $6.54^{\mathrm{b}}$ & $3.14^{\mathrm{d}}$ \\
\hline (E)2-Decenal ${ }^{2}$ & $4.07^{\mathrm{b}}$ & $2.41^{\mathrm{d}}$ & $2.42^{\mathrm{d}}$ & $2.18^{\text {de }}$ & $2.33^{\mathrm{d}}$ & $1.42^{\mathrm{e}}$ & $5.59^{\mathrm{a}}$ & $3.31^{\mathrm{c}}$ & $3.56^{\mathrm{bc}}$ \\
\hline 1-Octen-3-one ${ }^{3}$ & $0.356^{\text {de }}$ & $0.283^{\mathrm{e}}$ & $0.347^{\mathrm{de}}$ & $0.651^{\mathrm{a}}$ & $0.524^{\mathrm{b}}$ & $0.665^{\mathrm{a}}$ & $0.465^{\mathrm{bc}}$ & $0.680^{\mathrm{a}}$ & $0.395^{\mathrm{cd}}$ \\
\hline Dimethyl disulfide ${ }^{4}$ & $1.05^{\mathrm{b}}$ & $0.944^{\mathrm{c}}$ & $0.505^{\mathrm{e}}$ & $1.24^{\mathrm{a}}$ & $0.786^{\mathrm{d}}$ & $0.283^{\mathrm{g}}$ & $0.347^{\mathrm{f}}$ & $0.254^{\mathrm{g}}$ & $0.152^{\mathrm{h}}$ \\
\hline Dimethyl trisulfide ${ }^{4}$ & $0.104^{\mathrm{e}}$ & $0.727^{\mathrm{a}}$ & $0.032^{\mathrm{fg}}$ & $0.268^{\mathrm{c}}$ & $0.773^{\mathrm{a}}$ & $0.074^{\mathrm{ef}}$ & $0.182^{\mathrm{d}}$ & $0.500^{\mathrm{b}}$ & $0.016^{\mathrm{g}}$ \\
\hline Benzaldehyde $^{3}$ & $0.671^{\mathrm{e}}$ & $0.097^{\mathrm{g}}$ & $0.975^{\mathrm{d}}$ & $0.465^{\mathrm{f}}$ & $0.094^{\mathrm{g}}$ & $1.04^{\mathrm{d}}$ & $2.39^{\mathrm{b}}$ & $3.13^{\mathrm{a}}$ & $1.77^{\mathrm{c}}$ \\
\hline$(\mathrm{E}, \mathrm{E}) 2,4-\mathrm{Nonadienal}^{3}$ & $\mathrm{ND}^{5}$ & ND & ND & ND & ND & ND & $0.433^{\mathrm{a}}$ & $0.495^{\mathrm{a}}$ & $0.357^{\mathrm{a}}$ \\
\hline
\end{tabular}

${ }^{\mathrm{a}-\mathrm{h}}$ Means in a row followed by a different letter are different $(P \leq 0.05)$.

${ }^{1}$ Compounds quantified with $\mathrm{D}_{12}$-hexanal.

${ }^{2}$ Compounds quantified with $\mathrm{D}_{18}$-octanal.

${ }^{3}$ Compounds quantified with $\mathrm{D}_{6}$-dimethly trisulfide.

${ }^{4}$ Compounds quantified with relative abundance.

${ }^{5} \mathrm{ND}=$ not detected. 
Table 3. Recovery $(\mu \mathrm{g} / \mathrm{kg})$ of $D_{12}$-hexanal in rehydrated spray-dried powders at different $\mathrm{pH}$ values ${ }^{1}$

\begin{tabular}{lcc}
\hline $\mathrm{pH}$ at & $\begin{array}{c}\text { Evaluation } \\
\mathrm{pH}\end{array}$ & $\mathrm{D}_{12}$-hexanal \\
\hline 6.5 & 6.5 & $59.7^{\mathrm{a}}$ \\
6.5 & 5.5 & $35.5^{\mathrm{c}}$ \\
6.5 & 3.5 & $27.5^{\mathrm{d}}$ \\
5.5 & 6.5 & $47.2^{\mathrm{b}}$ \\
5.5 & 5.5 & $27.5^{\mathrm{cd}}$ \\
5.5 & 3.5 & $23.5^{\mathrm{de}}$ \\
3.5 & 6.5 & $24.7^{\mathrm{de}}$ \\
3.5 & 5.5 & $18.2^{\mathrm{e}}$ \\
3.5 & 3.5 & $22.3^{\mathrm{de}}$ \\
\hline${ }^{\mathrm{a}-\mathrm{e}}$ Means in a column followed by a different letter are different $(P$ \\
$\leq 0.05)$. \\
${ }^{1}$ All quantification was with 5-point standard curves with $\mathrm{R}^{2}>0.97$.
\end{tabular}

hexanal concentration decreased in all treatments when evaluated at $\mathrm{pH} 3.5$ (Table 2).

\section{DISCUSSION}

Cardboard flavor in whey proteins has been sourced to pentanal, heptanal, and nonanal in the presence of DMTS and 1-octen-3-one (Whitson et al., 2010). In general, WPC spray dried at $\mathrm{pH} 3.5$ had lower concentrations of pentanal, heptanal, nonanal, and DMTS. This result was consistent with the decreased cardboard flavor intensity in these samples. The WPC spray dried at $\mathrm{pH} 3.5$ exhibited soapy flavor at all evaluation $\mathrm{pH}$ values, whereas WPC spray dried at $\mathrm{pH} 5.5$ and 6.5 exhibited soapy flavor only when evaluated at $\mathrm{pH} 3.5$. Soapy flavor has also been documented in rehydrated instantized and noninstantized WPI, WPC80, and serum protein concentrate at neutral $\mathrm{pH}$, suggesting that this flavor is not solely due to $\mathrm{pH}$ (Drake et al., 2009; Wright et al., 2009; Evans et al., 2010), although White et al. (2013) reported that acidification increased soapy flavor in WPI solutions. The source of soapy flavor remains unknown. Cabbage flavor in whey proteins is due to increased concentrations of DMTS (Wright et al., 2006). The WPC in this study with concentrations of DMTS $>0.268 \mu \mathrm{g} / \mathrm{kg}$ all exhibited cabbage flavor, whereas cabbage flavor was absent in WPC with DMTS concentrations below that level. Dimethyl trisulfide is formed from the breakdown of methionine. First, methionine decomposes to methanethiol, which is then oxidized to DMDS and DMTS (Mahajan et al., 2004). Because pH 5.5 is close to the isoelectric point of whey proteins, methionine residues could have been more exposed at the surface of the protein molecules, allowing for more oxidation to occur and thus more DMTS to be generated.

Whey proteins have been reported to bind to flavor compounds and reduce flavor intensity (Hansen and
Heinis, 1991). In WPI, $\beta$-LG was the main protein responsible for the binding of flavor compounds (Kühn et al., 2007). Conformational changes could result in increased binding of VLOC at low $\mathrm{pH}$ compared with at $\mathrm{pH} 6.5$ or 5.5 . Below $\mathrm{pH} 3.5, \beta-\mathrm{LG}$ exists as a monomer rather than neutral $\mathrm{pH}$ dimer (Townend, 1969). At low $\mathrm{pH}$, the monomeric form of $\beta-\mathrm{LG}$ allows for more solvent accessibility to the hydrophobic region in the interior of the protein (Uhrinová et al., 2000). Because many off-flavor volatile compounds in WPC are hydrophobic, an increase in accessibility to the hydrophobic region of $\beta$-LG could decrease volatile compound release and reduce off-flavor intensities in ingredient applications. Consistent with our results, White et al. (2013) observed a decrease in VLOC in WPI that was acidified compared with a control that was not acidified. In experiment 2 , a reduction in $\mathrm{D}_{12}$-hexanal recovery was observed when the WPC was evaluated at $\mathrm{pH} 3.5$ for the WPC spray dried at $\mathrm{pH} 6.5$ or 5.5 , indicating an increase in association with the protein. The WPC spray dried at $\mathrm{pH} 3.5$ was unchanged regardless of the evaluation $\mathrm{pH}$ and always had decreased recovery of $\mathrm{D}_{12}$-hexanal compared with WPC spray dried at $\mathrm{pH} 6.5$ or 5.5. In addition, the higher amount of protonation of the volatile compounds not bound by protein at low $\mathrm{pH}$ makes them less soluble in water and more volatile (van Ruth and Villenueve, 2002). As such, greater volatility due to increased partitioning in headspace may significantly reduce concentrations of off-flavor volatile compounds in the final spray-dried product, consistent with the results observed in this study.

Kühn et al. (2008) found that WPI flavor binding behaved differently before and after heat and high pressure treatments. This was attributed to protein denaturation that weakened hydrophobic interactions and increased covalent interactions. It would make sense that proteins denatured during spray drying would increase covalent interactions between hexanal and whey proteins upon rehydration. Meynier et al. (2004) reported that hexanal and t-2-hexenal covalently bond to whey proteins. White et al. (2013) reported increases in cardboard and potato/brothy flavor intensities (along with soapy flavor) in noninstantized WPI that was acidified. The WPI used in that study was commercial and other studies have found significant differences between commercial and experimentally made whey proteins (Evans et al., 2010). These results led us to propose that the decreased protein interactions with aldehydes at low $\mathrm{pH}$ during spray drying resulted in greater availability of unbound (volatile) hexanal. Spray drying liquid WPC at $\mathrm{pH} 3.5$ volatilized more $\mathrm{D}_{12}$-hexanal, resulting in less in the subsequent powder. In experiment 1 , the WPC spray dried at pH 3.5 always had the lowest concentration of hexanal regardless of evaluation $\mathrm{pH}$. A 
combination of increased volatility in liquid WPC and decreased recovery of $\mathrm{D}_{12}$-hexanal in the powders spray dried at $\mathrm{pH} 3.5$ was observed in experiment 2 and led to the conclusion that VLOC are decreased during spray drying at $\mathrm{pH} 3.5$ because of increased volatility due to decreased protein interactions or decreased solubility, followed by increased association of VLOC with whey protein upon rehydration.

\section{CONCLUSIONS}

Whey proteins that are acidified to $\mathrm{pH} 3.5$ before spray drying have decreased intensities of off-flavors and decreased concentrations of many lipid oxidation compounds compared with those spray dried at higher $\mathrm{pH}$. Deuterated hexanal was more volatile in acidified liquid WPC retentate and less was recovered in the subsequent powder rehydrated to $\mathrm{pH}$ 3.5. The mechanism for decreased off-flavor intensities in WPC from retentate preacidified to $\mathrm{pH} 3.5$ appears to be increased volatility during the spray-drying process or increased flavor-protein interactions in the spray-dried powder upon rehydration. Preacidification of WPC for acidified beverage applications improves the flavor of acidic beverages into which such ingredients are incorporated.

\section{ACKNOWLEDGMENTS}

Funding was provided in part by the Dairy Research Institute (DRI; Rosemont, IL). The use of trade names does not imply endorsement nor lack of endorsement by those not mentioned.

\section{REFERENCES}

AOAC International. 2000. Official Methods of Analysis. 17th ed. AOAC International, Gaithersburg, MD.

Beecher, J. W., M. A. Drake, P. J. Luck, and E. A. Foegeding. 2008. Factors regulating astringency of whey protein beverages. J. Dairy Sci. 91:2553-2560

Campbell, R. E., R. E. Miracle, and M. A. Drake. 2011a. The effect of starter culture and annatto on the flavor and functionality of whey protein concentrate. J. Dairy Sci. 94:1185-1193.

Campbell, R. E., R. E. Miracle, P. Gerard, and M. A. Drake. 2011b. Effects of starter culture and storage on the flavor of liquid whey. J. Food Sci. 76:S354-S361.

Carunchia Whetstine, M. E.. A. E. Croissant, and M. A. Drake. 2005. Characterization of dried whey protein concentrate and isolate flavor. J. Dairy Sci. 88:3826-3839.

Childs, J. L., and M. A. Drake. 2010. Consumer perception of astringency in clear acidic whey protein beverages. J. Food Sci 75:S513-S521.

Croissant, A. E., E. J. Kang, R. E. Campbell, E. Bastian, and M. A Drake. 2009. The effect of bleaching agent on the flavor of liquid whey and whey protein concentrate. J. Dairy Sci. 92:5917-5927.

Drake, M. A., R. E. Miracle, and J. M. Wright. 2009. Chapter 15 Sensory properties of dairy proteins. Pages 429-448 in Milk Proteins: From Expression to Food. A. Thompson, M. Boland, and H. Singh, ed. Elsevier, Amsterdam, the Netherlands.
Evans, J., J. Zulewska, M. Newbold, M. A. Drake, and D. M. Barbano. 2009. Comparison of composition, sensory, and volatile components of thirty-four percent whey protein and milk serum protein concentrates. J. Dairy Sci. 92:4773-4791.

Evans, J., J. Zulewska, M. Newbold, M. A. Drake, and D. M. Barbano. 2010. Comparison of composition and sensory properties of $80 \%$ whey protein and milk serum protein concentrates. J. Dairy Sci. 93:1824-1843.

Frankel, E. N., W. E. Neff, and E. Selke. 1981. Analysis of autooxidized fats by gas chromatography mass spectrometry: VIII Volatile thermal decomposition products of pure hydroperoxides from autooxidized and photo sensitized methyl oleate, linoleate, and linolenate. Lipids 16:279-285.

Hansen, A. P., and J. J. Heinis. 1991. Decrease of vanillin flavor perception in the presence of casein and whey proteins. J. Dairy Sci 74:2936-2940

Jervis, S., R. Campbell, K. L. Wojciechowski, E. A. Foegeding, M. A. Drake, and D. M. Barbano. 2012. Effect of bleaching whey on sensory and functional properties of $80 \%$ whey protein concentrate. J. Dairy Sci. 95:2848-2862.

Kang, E. J., T. J. Smith, and M. A. Drake. 2012. Alternative bleaching methods for Cheddar cheese whey. J. Food Sci. 77:C818-823.

Kühn, J., T. Considine, and H. Singh. 2008. Binding of flavor compounds and whey protein isolate as affected by heat and high pressure treatments. J. Agric. Food Chem. 56:10218-10224.

Kühn, J., X. Q. Zhu, T. Considine, and H. Singh. 2007. Binding of 2-nonanone and milk proteins in aqueous model systems. J. Agric. Food Chem. 55:3599-3604

Liaw, I. W., H. Eshpari, P. S. Tong, and M. A. Drake. 2010. The impact of antioxidant addition on flavor stability of Cheddar and Mozzarella whey and Cheddar whey protein concentrate. J. Food Sci. 75:C559-C569.

Liaw, I. W., R. E. Miracle, S. M. Jervis, M. A. D. Listiyani, and M. A Drake. 2011. Comparison of the flavor chemistry and flavor stability of Mozzarella and Cheddar wheys. J. Food Sci. 76:C1188-1194.

Listiyani, M. A. D., R. E. Campbell, R. E. Miracle, L. O. Dean, and M. A. Drake. 2011. Influence of bleaching on flavor of $34 \%$ whey protein concentrate and residual benzoic acid concentration in dried whey proteins. J. Dairy Sci. 94:4347-4359.

Mahajan, S. S., L. Goddik, and M. C. Qian. 2004. Aroma compounds in sweet whey powder. J. Dairy Sci. 87:4057-4063.

Meynier, A., V. Rampon, M. Dalgalarrondo, and C. Genot. 2004. Hexanal and t-2-hexenal form covalent bonds with whey proteins and sodium caseinate in aqueous solution. Int. Dairy J. 14:681690.

NIST (National Institute of Standards and Technology). 2005. NIST Wiley Registry: NIST Mass Spectral Library. 8th ed. Wiley, Hoboken, NJ.

Pelegrine, D. H. G., and C. A. Gasparetto. 2005. Whey proteins solubility as function of temperature and $\mathrm{pH}$. Lebenson. Wiss. Technol. $38: 77-80$.

Schuck, P. 2013. Dairy protein powders. Pages 3-31 in Advances in Dairy Ingredients. G. W. Smithers, and M. A. Augustin, ed. Wiley-Blackwell, Ames, IA.

Tomaino, R. M., L. G. Turner, and D. K. Larick. 2004. The effect of Lactococcus lactis starter cultures on the oxidative stability of liquid whey. J. Dairy Sci. 87:300-307.

Townend, R., T. T. Herskovits, S. N. Timasheff, and M. J. Gorbunoff 1969. The state of amino acid residues in $\alpha$-lactoglobulin. Arch. Biochem. Biophys. 129:567-580.

Uhrinová, S., M. H. Smith, G. B. Jameson, D. Uhrin, L. Sawyer, and P. N. Barlow. 2000. Structural changes accompanying pH-induced dissociation of the $\beta$-lactoglobulin dimer. Biochemistry 39:35653574

USDA. 2011. Dairy Products 2011 Summary: USDA. Accessed Jul. 25, 2011. http://usda.mannlib.cornell.edu/usda/current/DairProdSu/ DairProdSu-04-27-2011.pdf.

van Ruth, S. M., and E. Villenueve. 2002. Influence of $\beta$-lactoglobulin, $\mathrm{pH}$, and presence of other aroma compounds on the air/liquid partition coefficients of 20 aroma compounds varying in functional group and chain length. Food Chem. 79:157-164. 
White, S. S., K. M. Fox, S. M. Jervis, and M. A. Drake. 2013. Influence of heating and acidification on the flavor of whey protein isolate. J. Dairy Sci. 96:1366-1379.

Whitson, M. E., R. E. Miracle, E. Bastian, and M. A. Drake. 2011. Effect of liquid retentate storage on flavor of spray-dried whey protein concentrate and isolate. J. Dairy Sci. 94:3747-3760.

Whitson, M. E., R. E. Miracle, and M. A. Drake. 2010. Sensory characterization of chemical components responsible for cardboard flavor in whey protein. J. Sens. Stud. 25:616-636.
Wright, B. J., S. E. Zevchak, J. M. Wright, and M. A. Drake. 2009. Impact of agglomeration on flavor and flavor stability of whey proteins. J. Food Sci. 74:S17-S29.

Wright, J. W., M. E. Carunchia-Whetstine, R. E. Miracle, and M. A. Drake. 2006. Characterization of cabbage off-flavor in whey protein isolate. J. Food Sci. 71:C86-C90. 